\title{
Pengembangan Kartu Domano (Domino Matematika Trigono) Sebagai Media Pembelajaran Pada Matakuliah Trigonometri
}

\author{
Kristian Tantra Sidarta, Tri Nova Hasti Yunianta \\ tantra.kristian@gmail.com, trinova.yunianta@staff.uksw.edu \\ Pendidikan Matematika, Fakultas Keguruan dan Ilmu Pendidikan, Universitas Kristen Satya Wacana \\ The Development Of Domano Card (Trigono Mathematics Dominoes) As A Learning Media For \\ Trigonometry Courses
}

\begin{abstract}
This research aims is to develop a learning media called Domano Card, that is an abbreviation from Trigono mathematics Dominoes. This media is expected to be valid, effective, and practical to be used as a learning tool for Trigonometry Courses in the college. It is consists of three sets of Domano cards, game boards, and game rules. This Domano Card contains of the pairs of questions and answers. This research type is Research Development $(R \& D)$ with ADDIE model (Analyze, Design, Development, Implementation, Evaluate). The subject of this research is 64 active students of Mathematics Education, Satya Wacana Christian University in Trigonometry course. Domano cards are developed based on the students' learning styles. Validity test was done by 2 validators, there are media experts and material experts It has obtained media feasibility result of $98.71 \%$ with very decent category and the result of material feasibility of $92.5 \%$ with very decent category. The effectiveness test was done by Paired Samples t-test with SPSS 17. It is indicated that there is a significant differences after the use of Domano Card with the mean value improvement from 57 to 73 . The respondents of practicality test are lecturer of Trigonometry course and the lecturer assistant class that obtained $89 \%$ with very good category. Based on this development research, it can be concluded that Domano Card media is valid, effective, and practical use as a means of selflearning exercises for students in Trigonometry courses.
\end{abstract}

Keywords: Development, Instructional Media, Domano Card, Trigonometry

Received date: 13 Desember 2018

Revised date: 7 Januari 2019

Accepted date: 22 Januari 2019

\section{PENDAHULUAN}

Matematika sebagai suatu mata pelajaran pokok yang diajarkan mulai dari jenjang sekolah dasar hingga ranah universitas. Menurut Subarinah (Kriswandani \& Wahyudi, 2013: 10) matematika merupakan suatu ilmu deduktif, aksiomatik, formal, hirarkis, abstrak, bahasa simbol yang padat arti dan semacamnya adalah sebuah sistem yang dapat digunakan untuk mengatasi persoalan-persoalan nyata. Pada implementasinya di kelas, matematika mempunyai banyak permasalahan. Secara umum permasalahan yang muncul disebabkan oleh beberapa hal diantaranya: pemilihan model atau metode pembelajaran yang kurang tepat karena tidak sesuai dengan karakteristik materi, kemampuan pendidik yang rendah, kemampuan dasar peserta didik yang rendah, dan kurangnya media pembelajaran yang dapat digunakan dalam pembelajaran di kelas. Berdasarkan masalah yang timbul tersebut, diperlukan solusi mengenai hal tersebut. Salah satunya difokuskan untuk meneliti tentang permasalahan kurangnya media pembelajaran.

Media pembelajaran menurut Arsyad (2011: 4) adalah perantara yang berupa sumber belajar atau wahana fisik yang mengandung materi instruksional yang dapat dimanfaatkan siswa untuk menunjang kegiatan belajar. Media pembelajaran dapat memperjelas penyajian pesan dan informasi sehingga dapat memperlancar dan meningkatkan proses dan hasil belajar. Secara umum media pendidikan menurut Petrus (2013: 84) mempunyai kegunaan memperjelas penyajian pesan agar tidak terlalu bersifat verbalistis (dalam bentuk kata-kata tertulis atau lisan belaka) dan mengatasi keterbatasan ruang, waktu dan daya indera. Prinsip pemilihan media pembelajaran menurut Harjanto (1997: 238) yaitu: tujuan, keterpaduan, keadaan peserta didik, ketersediaan, mutu teknis, dan biaya. 
Berdasarkan hasil prapenelitian melalui wawancara dengan dosen pengajar mata kuliah trigonometri pada bulan Januari 2017, diperoleh hasil bahwa terdapat permasalahan utama pembelajaran di kelas adalah kurangnya media pembelajaran yang dapat digunakan sebagai sarana latihan soal bagi mahasiswa. Di dalam kelas, pembelajaran secara umum dilakukan dengan dosen menjelaskan materi pembelajaran, kemudian mahasiswa diberikan beberapa contoh soal yang terkait materi untuk dikerjakan. Mahasiswa cukup aktif dalam mengikuti pembelajaran di kelas, namun dinilai mahasiswa kurang berlatih soal mandiri karena banyak waktu dihabiskan untuk menjelaskan materi dan membahas contoh soal saja. Oleh karena itu, dibutuhkan sebuah media pembelajaran sebagai latihan soal mandiri yang dapat membantu mahasiswa dalam pembelajaran mata kuliah Trigonometri ini.

Salah satu inovasi media pembelajaran yang dapat dikembangkan sebagai media latihan soaladalah permainan matematika. Permainan matematika menurut Syafik (2012: 24) adalah suatu jenis permainan yang berkaitan dengan bidang matematika. Obyek atau sesuatu yang digunakan dalam permainan itu tentunya adalah obyek atau unsur yang terkandung dalam kajian matematika misalnya konsep dalam aritmatika, geometri, aljabar, trigonometri dan sebagai nya. Pembelajaran matematika yang dikombinasikan dengan permainan dapat memberikan dampak yang menyenangkan bagi mahasiswa, mengurangi tingkat kejenuhan materi, serta secara tidak langsung mahasiswa telah belajar banyak hal baru ketika sedang bermain. Permainan matematika yang dapat dikembangkan diantaranya adalah catur angka, ular tangga, monopoli,kartu domino matematika dan sebagainya.

Berdasarkan hasil prapenelitian berupa angket gaya belajar didapat hasil 49\% (32 mahasiswa) memiliki gaya belajar dominan visual, 29\% (19 mahasiswa) memiliki gaya belajar dominan kinestetik, dan 22\% (13 mahasiswa) memiliki gaya belajar dominan audiotori. Pengembangan media pembelajaran mempunyai tujuan utama untuk pemenuhan mahasiswa sesuai dengan gaya belajar yang dominan dimiliki, namun tanpa mengabaikan mahasiswa dengan gaya belajar lainnya. Terdapat beberapa jenis permainan matematika yang dapat dikembangkan sebagai media latihan soal mandiri.Domino matematika merupakan permainan matematika yang relevan untuk dimainkan dalam kapasitas umur mahasiswa. Kisaran usia seorang mahasiswa yaitu antara 18-23 tahun, dinilai telah memiliki pengetahuan dan kemampuan yang cukup untuk memainkan pasangan kartu domino matematika. Kartu domino matematika dalam perkembangannya masih jarang digunakan dalam pembelajaran dan diketahui oleh mahasiswa, peneliti ingin memperkenalkan media pembelajaran berupa kartu domino matematika ini. Oleh karena itu, pengembangan media pembelajaran berupa domino matematika untuk mata kuliah Trigonometri dipandang sebagai hal yang perlu.

Model desain pengembangan yang digunakan dalam proses pengembangan media kartu domino matematika materi trigonometri ini adalah model ADDIE. Model ini terdiri dari lima fase atau tahapan utama, yaitu Analysis, Desain, Development, Implementation, Evaluation. Kelima fase atau tahap dalam model ADDIE perlu dilakukan secara sistemik dan sistematik (Pribadi, 2011: 125). Asumsi awal dari pengembangan permainan kartu domino matematika dalam mata kuliah trigonometri ini adalah dosen dan mahasiswa dapat dengan mudah mempergunakan produk media secara efektif, produk media yang dikembangkan dapat menyediakan fasilitas pembelajaran yang mengembangkan kemandirian mahasiswa, dan dalam implementasinya di kelas dapat berlangsung dengan baik. Keunggulan utama dari domino ini adalah desain media yang bagus, pemilihan bahan yang baik serta soal-soal yang disajikan dalam media telah disusun dengan tingkat kesulitan yang mendorong dan menantang mahasiswa.

Penggunaan kartu domino dalam pembelajaran sebelumnya telah dilakukan dalam penelitian yang dilakukan oleh Nengsih \& Rochmawati (2014) yaitu pengembangan kartu domino sebagai media pembelajaran akuntansi pada materi ayat jurnal penyesuaian dengan hasil persentase kelayakan $(82,46 \%)$ dengan kategori sangat layak dan respons siswa yang sangat baik dengan persentase sebesar $(95,4 \%)$. Selain itu, penelitian yang dilakukanoleh Larasati \& Poedjiastuti (2016) yang bertujuan untuk mengembangkan kartu domino pada materi unsur bagi siswa SMALB tunarungu memberikan hasil penilaian validasi sangat layak, siswa memberikan respon positif dan peningkatan skor gain pada kategori sedang.

Berdasarkan hasil prapenelitian, analisis kebutuhan gaya belajar serta kajian literatur, kartu domino matematika dapat dikembangkan sebagai media pembelajaran yang dapat disesuaikan dengan kebutuhan pendidik dan peserta didik di dalam kelas. Oleh karena itu perlu diadakan tindak lanjut untuk meneliti dan mengembangkan media pembelajaran yang memanfaatkan kartu domino 
matematika. Harapan dan tujuan dari penelitian ini adalah mengembangkan Kartu Domano (Domino Matematika Trigonometri) pada Mata Kuliah Trigonometri sebagai media pembelajaran yang valid, efektif, dan praktis.

\section{KAJIAN PUSTAKA}

Media adalah segala sesuatu yang dapat digunakan untuk menyalurkan pesan dari pengirim ke penerima sehingga dapat digunakan untuk menyalurkan pesan dari pengirim ke penerima. Penggunaan media dapat merangsang pikiran, perasaan, perhatian, dan minat serta perhatian siswa sedemikian rupa sehingga proses belajar terjadi (Sadiman dkk, 2007).

Trigonometri adalah mata kuliah wajib yang harus dipelajari dalam jurusan Pendidikan Matematika, diberikan pada semester 2 dengan bobot 3 SKS. Trigonometri (dari bahasa Yunani Trigono $=$ tiga sudut dan Metro $=$ mengukur) adalah cabang matematika yang berhadapan dengan sudut segitiga dan fungsi trigonometrik, seperti sinus, cosinus, tangen dan sebagainya (Setyawati \& Handayanto, 2011).

Indriana (2011) mengatakan bahwa kartu domino merupakan salah satu media yang masuk dalam kategori flashcard. Definisi dari flashcard menurut Arsyad (2011) adalah kartu kecil yang berisi gambar, teks, atau tanda simbol yang mengarahkan siswa kepada sesuatu yang berhubungan dengan gambar. Flashcard biasanya berukuran $8 \times 12 \mathrm{~cm}$, atau dapat disesuaikan dengan besar kecilnya kelas yang dihadapi.

Definisi domino matematika menurut Sundayana (2013: 151-152) merupakan sebuah kartu matematika yang didesain menyerupai kartu domino. Kartu domino matematika berisi berbagai pasangan soal dan jawaban, permainan ini dapat dimainkan oleh 2-4 orang. Materi soal yang digunakan pun dapat disesuaikan dengan materi yang diajarkan.

Model pengembangan yang digunakan adalah ADDIE, digunakan model pengembangan ADDIE karena karakteristik model pengembangan ini sangat cocok digunakan untuk mengembangkan media pembelajaran berbentuk permainan dan media cetak. Berikut tahapan dari model pengembangan ADDIE dapat dilihat pada Tabel 1.

Tabel 1. Deskripsi ADDIE

\begin{tabular}{ll}
\hline A & Analisis kebutuhan untuk menentukan masalah dan solusi yang tepat dan menentukan \\
Analysis & kompetensi mahasiswa. \\
\hline $\begin{array}{l}\text { D } \\
\text { Design }\end{array}$ & Menentukan media yang akan dikembangkan dan digunakan pada proses pembelajaran. \\
\hline $\begin{array}{l}\text { Development } \\
\text { I }\end{array}$ & Memproduksi media yang akan digunakan dalam proses pembelajaran. \\
Implementation & Melaksanakan proses pembelajaran dengan menerapkan media yang diproduksi \\
\hline $\mathbf{E}$ & $\begin{array}{l}\text { Melakukan evaluasi terhadap media yang dikembangkan dan evaluasi hasil belajar } \\
\text { Evaluation }\end{array}$ \\
\hline
\end{tabular}

\section{METODE PENELITIAN}

Penelitian ini termasuk jenis penelitian pengembangan atau Research and Development (R\&D) yang merupakan suatu proses atau langkah-langkah untuk mengembangkan suatu produk baru atau menyempurnakan produk yang telah ada dan dapat dipertanggung jawabkan (Sukmadinata, 2009: 164). Produk yang dihasilkan dalam penelitian ini adalah seperangkat kartu Domano (Domino Matematika Trigono) pada materi Trigonometri. Subjek yang digunakan sebagai sampel pada penelitian ini adalah 64 mahasiswa Program Studi Pendidikan Matematika, Fakultas Keguruan dan Ilmu Pendidikan, Universitas Kristen Satya Wacana yang aktif dan menempuh mata kuliah Trigonometri. Penelitian ini dilaksanakan pada semester II tahun ajaran 2016/2017. Semua mahasiswa tersebut akan menggunakan kartu domino matematika sebagai media latihan soal dalam pembelajaran. Prosedur pengembangan yang digunakan dalam penelitian ini adalah prosedur pengembangan menurut Sugiyono. Berikut ini adalah prosedur pengembangan Produk: 1. Potensi Masalah $\rightarrow 2$. Pengumpulan Data $\rightarrow 3$. Desain Produk $\rightarrow$ 4. Validasi Desain Media $\rightarrow 5$. Revisi Produk $\rightarrow 6$. Uji Coba Produk $\rightarrow$ 7. Revisi Produk $\rightarrow$ 8. Revisi Produk $\rightarrow$ 9. Uji Coba Pemakaian $\rightarrow 10$. Revisi Produk $\rightarrow$ 11. Produk Masal (Sugiyono, 2012: 298). 
Model pengembangan yang digunakan dalam penelitian ini adalah ADDIE (Analysis, Design, Development, Implementation, Evaluation) yang dikembangkan oleh Raiser dan Mollenda yang meliputi:

Analisis (Analysis)

Dalam penelitian ini tahap analisis meliputi:

1) Analisis Mahasiswa

Merupakan analisis keadaan mahasiswa didalam kelas secara umum yang akan digunakan sebagai subjek, terkhususnya proporsi jenis kelamin yaitu 64 orang mahasiswa yang terdiri dari 17 laki-laki dan 47 perempuan.

2) Analisis Gaya Belajar

Analisis selanjutnya adalah untuk mengetahui gaya belajar mahasiswa tersebut. Proses pengambilan data menggunakan angket gaya belajar.

3) Analisis Kurikulum

Tahap terakhir merupakan analisis tentang kurikulum dan materi yang dilaksanakan pada mata kuliah Trigonometri, meliputi materi yang akan diajarkan pada saat penelitian dilaksanakan.

\section{Desain (Design)}

Pada proses desain merupakan tindak lanjut dari tahap analisis. Tahap ini media mulai dikembangkan sesuai dengan hasil dari analisis umum keadaan mahasiswa, gaya belajar mahasiswa, kurikulum serta materi yang akan diajarkan pada saat penelitian dilaksanakan.

\section{Pengembangan (Development)}

Pada langkah ini merupakan tahap membuat media yang telah di desain berdasarkan kebutuhan mahasiswa. Media ini kemudian akan diuji dalam dua tahap: a) expert judgment atau uji ahli dengan responden ahli media dan ahli materi; b) uji kelompok kecil dengan responden terbatas yaitu dengan beberapa mahasiswa Progdi Pendidikan Matematika angkatan 2012 sebagai pengguna awal media. Pada tahap ini juga dikembangkan instrument penelitian seperti lembar angket gaya belajar siswa, soal pretest dan posttest, dan lembar validasi media

\section{Implementasi (Implementation)}

Pada langkah ini adalah penyampaian dan penggunaan media untuk mata kuliah Trigonometri kepada subjek penelitian yaitu 64 mahasiswa yang akan digunakan sebagai media latihan soal untuk mata kuliah Trigonometri.

\section{Evaluasi (Evaluation)}

Proses yang dilakukan untuk memberi nilai terhadap hasil media pembelajaran yang telah dikembangkan. Pada tahap evaluasi ini meliputi hasil belajar mahasiswa setelah penggunaan media kartu Domano, keefektifan dan kepraktisan media, serta pendapat mahasiswa mengenai penggunaan media.

Analisis data dalam penelitian ini dilakukan dengan menganalisis angket gaya belajar mahasiswa, menentukan validitas media, kepraktisan media, dan keefektifan media kartu Domano pada mata kuliah Trigonometri. Selain itu, soal pretest dan posttest yang akan diujikan juga harus dianalisis validitasnya sehingga soal yang diujicobakan kepada mahasiswa merupakan soal yang valid.

\section{Analisis Data Gaya Belajar}

Data yang diperoleh melalui angket gaya belajar siswa dalam bentuk kualitatif yang berupa kata-kata akan diubah menjadi nilai kuantitatif dengan langkah-langkah sebagai berikut :

1) Jenis data yang diambil berupa data kualitatif selanjutnya diubah menjadi data kuantitatif dengan ketentuan pada Tabel 2 .

Tabel 2. Aturan Pemberian Skala

\begin{tabular}{lc}
\hline Keterangan & Skor \\
\hline Selalu (SL) & 5 \\
\hline Sering (Sr) & 4 \\
\hline Kadang-kadang (Kd) & 3 \\
\hline Jarang (Jr) & 2 \\
\hline Tidak pernah (TP) & 1 \\
\hline
\end{tabular}

2) Setelah data terkumpul kemudian menghitung rata-rata skor dari masing-masing tipe gaya belajar (visual, audiotori, dan kinestetik) dengan rumus modifikasi skala Likert sebagai berikut 
Pengembangan Kartu Domano (Domino Matematika Trigono) Sebagai Media Pembelajaran Pada

Mata Kuliah Trigonometri (Kristian Tantra Sidarta, Tri Nova Hasti Yunianta)

$$
\mu=\frac{\Sigma \mathrm{x}}{N} \quad \begin{aligned}
& \text { Keterangan: } \\
& \mu: \text { nilai rata-rata } \\
& \Sigma \mathrm{x}: \text { jumlah skor } \\
& \mathrm{N}: \text { :jumlah pertanyaan pada setiap kategori gaya belajar }
\end{aligned}
$$

3) Berdasarkan skor rata-rata yang diperoleh pada setiap kategori gaya belajar, terdapat tiga kategori gaya belajar yaitu visual, audiotori, dan kinestetik dan mahasiswa hanya memiliki satu gaya belajar yang dominan. Gaya belajar tersebut dapat ditentukan berdasarkan rata-rata tertinggi di antara ketiga kategori gaya belajar yang diperoleh mahasiswa.

\section{Analisis Data Validasi Media dan Lembar kepraktisan}

Data yang diperoleh melalui lembar validasi ahli media dan ahli materi kemudian dikonversi kedalam bentuk data kuantitatif dengan pedoman pada Tabel 3.

Tabel 3. Aturan Pemberian Skala

\begin{tabular}{lc}
\hline Keterangan & Skor \\
\hline Sangat Baik (SB) & 5 \\
\hline Baik (B) & 4 \\
\hline Cukup (C) & 3 \\
\hline Kurang (K) & 2 \\
\hline Sangat Kurang (SK) & 1 \\
\hline
\end{tabular}

1) Mengkuantitatifkan hasil checking sesuai dengan indikator yang telah ditetapkan dengan memberikan skor sesuai dengan bobot yang telah ditentukan.

2) Membuat tabulasi data

3) Mengubah nilai tiap aspek kriteria dalam masing-masing komponen aplikasi matematika menjadi nilai kualitatif dengan kriteria kategori penilaian dalam ketentuan pada Tabel 4.

$$
\text { Persentase penilaian }=\frac{\text { skor } \text { hasil penelitian }}{\text { skor } \text { maksimal }} \times 100 \%
$$

Kategori dalam Tabel 4 dikatakan valid jika minimal termasuk dalam kategori cukup.

Tabel 4. Kriteria Penilaian

\begin{tabular}{lll}
\hline No. & Rentang & Kategori Kualitatif \\
\hline $\mathbf{1}$ & $84 \% \leq$ skor $\leq 100 \%$ & Sangat Baik \\
\hline $\mathbf{2}$ & $68 \% \leq$ skor $<84 \%$ & Baik \\
\hline $\mathbf{3}$ & $52 \% \leq$ skor $<68 \%$ & Cukup \\
\hline $\mathbf{4}$ & $36 \% \leq$ skor $<52 \%$ & Kurang \\
\hline $\mathbf{5}$ & $20 \% \leq$ skor $<36 \%$ & Sangat Kurang \\
\hline
\end{tabular}

\section{Keefektifan Media Kartu Domano}

Keefektifan media kartu Domano ini ditentukan berdasarkan hasil belajar pretest dan posttest serta berdasarkan hasil lembar pendapat mahasiswa. Hasil lembar pendapat mahasiswa akan dianalisis secara kualitatif dan kuantitatif. Data hasil belajar mahasiswa yang telah terkumpul kemudian dianalisis signifikansi peningkatannya dengan nilai pretest yang dihitung dengan uji Paired Samples $T$-test dengan program SPSS 17. Media yang dikembangkan dapat dikatakan efektif apabila didapat kesimpulan terdapat pengaruh atau perbedaan yang signifikan setelah penggunaan media tersebut.

\section{Analisis Data Soal Pretest dan Posttest}

Sebelum instrument soal pretest dan posttest digunakan dalam penelitian, maka instrument tersebut akan diuji tingkat validitasnya untuk digunakan. Validitas merupakan derajat ketepatan antara data yang terjadi pada objek penelitian dengan daya yang dilaporkan oleh peneliti. Soal pretest dan posttest melalui tahap validasi oleh 2 validator yaitu Dosen Progdi Pendidikan Matematika UKSW.

\section{HASIL DAN PEMBAHASAN}

Berdasarkan penelitian yang dilakukan, diperoleh media pembelajaran kartu Domano (Domino Matematika Trigono) yang dikembangkan dengan menggunakan model desain 
pengembangan ADDIE yang terdiri dari lima tahap utama yang dijelaskan melalui langkah-langkah berikut:

\section{Analyze (Analisis)}

\section{Analisis Siswa}

Analisis umum ini merupakan analisis terhadap mahasiswa untuk menggambarkan proporsi jenis kelamin dalam subjek penelitian. Subjek dari penelitian ini adalah mahasiswa Progdi Pendidikan Matematika Universitas Kristen Satya Wacana yang sedang menempuh mata kuliah Trigonometri sebanyak 64 mahasiswa. Berdasarkan hasil analisis, subjek terbagi atas 17 mahasiswa dan 47 mahasiswi.

\section{Analisis Gaya Belajar}

Analisis gaya belajar mahasiswa digunakan untuk mengetahui tipe gaya belajar subjek penelitian, sehingga pengembangan dari kartu Domano sesuai dengan tipe gaya belajar mahasiswa secara mayoritas. Instrumen yang digunakan adalah angket gaya belajar mahasiswa yang terdiri dari gaya belajar visual, audiotori, dan kinestetik. Berdasarkan hasil analisis gaya belajar subjek secara mayoritas digolongkan dalam tipe gaya belajar kinestetik. Hasil analisis gaya belajar mahasiswa terdapat pada Diagram 1.



Diagram 1. Proporsi Gaya Belajar Mahasiswa

Berdasarkan Diagram 1, dapat dilihat bahwa mahasiswa dengan gaya belajar visual lebih mendominasi dibandingkan dengan mahasiswa dengan gaya belajar lainnya. Persentase gaya belajar visual sebesar 50\% (32 mahasiswa) dari seluruh subjek penelitian. Gaya belajar visual adalah proses atau cara belajar yang cenderung menggunakan visual dan indera penglihatan untuk menyerap informasi dan pengetahuan baru. Mahasiswa dengan gaya belajar visual lebih menyukai belajar yang menggunakan gambar, diagram dan tulisan yang nyata.

Gaya belajar Kinestetik pada Diagram 1. menunjukan persentase sebesar 30\% (19 mahasiswa) dari seluruh subjek penelitian. Gaya belajar kinestetik adalah cara belajar melalui gerakan-gerakan sebagai sarana untuk menerima informasi baru. Mahasiswa dengan gaya belajar kinestetik cenderung belajar dengan bergerak, menyentuh, dan melakukan sesuatu kegiatan.

Gaya belajar Audiotori pada Diagram 1 menunjukan persentase sebesar 20\% (13 mahasiswa) dari seluruh subjek penelitian. Gaya belajar audiotori adalah cara untuk menyerap informasi dengan mengandalkan indera pendengarannya. Mahasiswa dengan gaya belajar audiotori dapat belajar lebih cepat dengan diskusi verbal atau mendengarkan penjelasan dari dosen.

\section{Analisis Kurikulum}

Tahap ini hasil analisis kurikulum diperoleh bahwa untuk Progdi Pendidikan Matematika di Universitas Kristen Satya Wacana menggunakan Kurikulum Nasional Republik Indonesia. Penelitian yang dilaksanakan pada semester genap tahun ajaran 2016/2017 ini berisi enam kompetensi dasar yang akan diajarkan pada mata kuliah Trigonometri ini diantaranya: 1)pengertian trigonometri; 2)perbandingan trigonometri sudut berelasi; 3) ukuran sudut dan Diagram trigonometri; 4)persamaan trigonometri; 5) aturan sinus, aturan cosinus, luas segitiga sembarang dan luas segi-n beraturan; dan 6) lingkaran dan segitiga.

\section{Design (Desain)}

Tahap desain merupakan inti dari langkah analisis, yaitu mempelajari masalah dan menemukan solusi alternatif melalui langkah analisis angket gaya belajar mahasiswa dan analisis 
umum. Berdasarkan hasil angket gaya belajar dan analisis umum, maka ditentukan langkah-langkah sebagai berikut :

\section{Menentukan Kompetensi Dasar}

Penelitian ini dilakukan di Universitas Kristen Satya Wacana yang telah menggunakan Kurikulum Nasional Republik Indonesia. Pengembangan media kartu Domano memperhatikan hasil analisis gaya belajar siswa dan standar pembelajaran yang sesuai dengan kurikulum yang digunakan. Materi mata kuliah Trigonometri yang akan dikembangkan terdiri dari enam kompetensi dasar. Konten materi yang digunakan pada media juga akan disesuaikan dengan keenam kompetensi dasar tersebut. Penyajian proporsi soal juga ditentukan secara seimbang berdasarkan banyaknya materi.

\section{Menentukan Tujuan Pembelajaran}

Adapun tujuan pembelajaran yang digunakan dalam pengembangan media kartu Domano ini antara lain :(1) pengertian trigonometri; (2)perbandingan trigonometri sudut berelasi; (3)ukuran sudut dan Diagram trigonometri; (4)persamaan trigonometri; (5)aturan sinus, aturan cosinus, luas segitiga sembarang dan luas segi-n beraturan; dan (6)lingkaran dan segitiga. Materi dari kartu Domano ini disusun sehingga mencakup keseluruhan keenam tujuan pembelajaran tersebut.

\section{Development (Pengembangan)}

\section{Memilih Strategi Pembelajaran}

Analisis gaya belajar menunjukan bahwa sebagian besar mahasiswa mempunyai tipe gaya belajar visual, berdasarkan hasil tersebut maka desain dari Kartu Domano yang lebih dominan dan apik namun tetap memperhatikan unsur gaya belajar kinestetik dan audiotori. Unsur visual yang disajikan dalam media kartu Domino ini meliputi pemilihan desain latar belakang media yang apik, penuh warna, desain dan penggunaan papan permainan dengan gambar menarik, pemilihan jenis, warna, serta ukuran huruf yang baik seperti contoh pada Gambar 1, Gambar 2, dan Gambar 3.

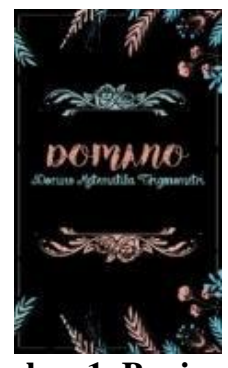

Gambar 1. Bagian Belakang dari Kartu Domano
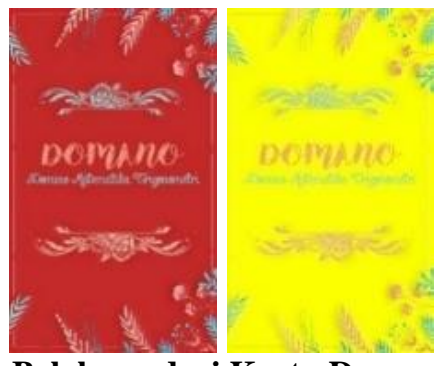

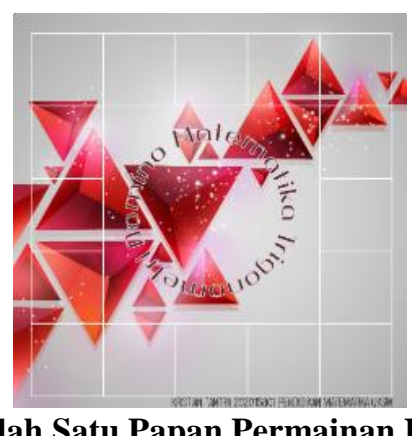

Gambar 3. Salah Satu Papan Permainan Kartu Domano

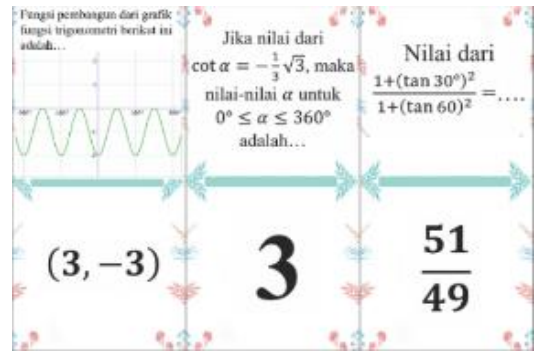

Gambar 2. Bagian Muka dari Kartu Domano

Unsur Audiotori dalam media permainan kartu Domano ini terdapat saat mahasiswa berdiskusi untuk mengerjakan soal dan saat mahasiswa diharuskan untuk mengajarkan teman sekelompoknya dalam memainkan kartu Domano tersebut. Unsur Kinestetik dalam media permainan kartu Domano ini didapat saat mahasiswa harus menulis mengerjakan soal, menaruh jawaban kartu pada papan permainan, serta pemain diharuskan menyusun kartu tersebut agar terbentuk pola kartu yang diinginkan. Penyusunan kartu Domino ini hanya akan menghasilkan satu susunan kartu sehingga kartu pertama yang dikeluarkan akan terpasang dengan kartu terakhir yang dikeluarkan sehingga seluruh pasangan kartu akan terbentuk susunan melingkar dengan contoh seperti Gambar 4. 


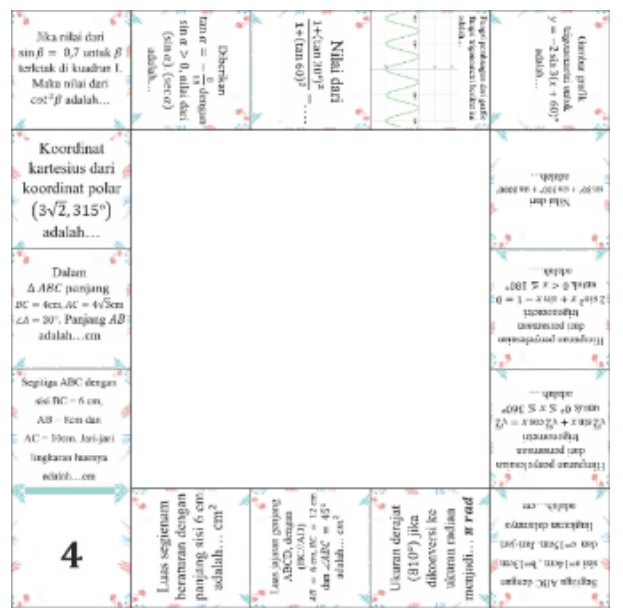

Gambar 4. Tata Susunan Kartu Domano

\section{Memilih Teknologi dan Media}

Pengembangan kartu Domat ini menggunakan media software Corel Draw X7 dan Photoshop CC 2015.5 yang kemudian disusun menjadi sebuah rangkaian kartu yang dapat dimainkan dengan baik. Setelah media dirancang menggunakan software komputer tersebut kemudian dicetak dan dipotong sesuai dengan bentuk yang diinginkan.

\section{Memilih Materi Pembelajaran}

Kartu Domano ini digunakan dalam mata kuliah Trigonometri, dan telah disesuaikan dengan proses kegiatan belajar mahasiswa subjek, yang akan digunakan sebagai media latihan soal pembelajaran bagi mahasiswa.

\section{Pembuatan Kartu Domano}

Kartu Domano untuk materi Trigonometri ini merupakan seperangkat kartu yang akan dimainkan oleh sekelompok mahasiswa.

\section{a. Tiga Set Kartu Domano}

Komponen-komponen yang terdapat dalam Kartu Domano ini adalah :

Kartu Domano yang dikembangkan ini terdiri dari tiga set kartu yang berbeda yaitu: (1) kartu merah; (2) kartu kuning; dan (3) kartu hitam. Tiap-tiap set kartu terdiri dari 16 buah kartu yang memiliki soal yang berbeda dan telah disesuaikan dengan tujuan pembelajaran. Dalam satu buah kartu terdiri dari bagian atas (pertanyaan) dan bagian bawah (jawaban) seperti Gambar 5.

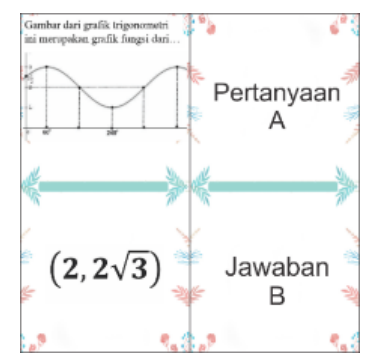

\section{Gambar 5. Bagian Kartu Domano}

Tujuan dari pembuatan tiga set kartu adalah untuk menambah variasi soal tanpa membuat mahasiswa jenuh dengan bermain di satu jenis kartu. Tiga set kartu merah, kuning, hitam ini tidak hanya dibedakan dari warna latar belakangnya saja, namun memiliki soal dengan varian yang berbeda untuk proporsi tiap indikator pembelajaran yang sama. Jumlah kartu dalam satu set kartu hanya berjumlah 16 kartu. Sehingga jika set kartu tersebut dimainkan oleh 4 orang maka masing-masing akan mendapat 4 kartu, dan jika dimainkan oleh 3 orang maksimal pemain kan mendapat 6 kartu. Efisiensi dari pemakaian waktu juga menjadi pertimbangan jumlah kartu yang dibentuk dalam set kartu Domano ini.

\section{b. Papan Permainan Domano}

Papan permainan Domano ini dibentuk bertujuan untuk memfasilitasi mahasiswa dalam bermain kartu Domano ini jika sulit untuk mendapat ruang bermain yang luas. Papan ini didesain 
dengan bentuk persegi yang mempunyai latar muka yang berwarna untuk menarik perhatian mahasiswa. Dalam sebuah perangkat kartu Domano ini terdiri dari $7+1$ papan permainan, yaitu 7 papan karton dan 1 buah papan kayu sebagai tempat pengemasannya. Beberapa contoh papan permainan Domano dapat dilihat pada Gambar 6.

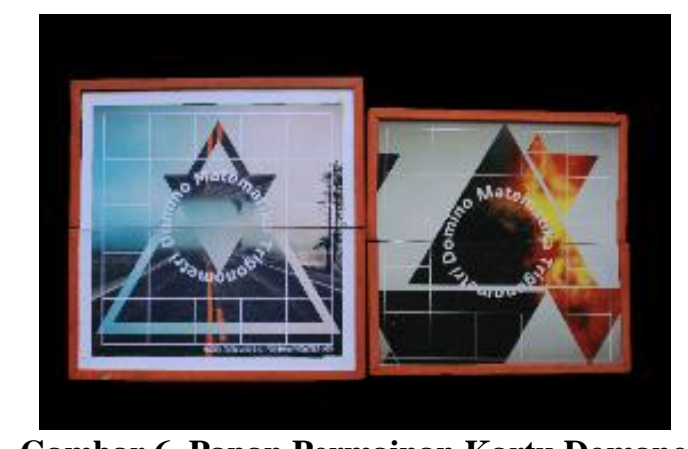

Gambar 6. Papan Permainan Kartu Domano

\section{c. Aturan Permainan}

Aturan permainan Domano ini didesain dengan tujuan agar mahasiswa dapat berlatih soal mandiri dan juga mengajari rekannya. Tujuan utama dari permainan ini bukan hanya mahasiswa tersebut berlatih soal-soal, namun mahasiswa tersebut juga dituntut untuk mengajari temannya tentang soal yang dapat dijawab. Berikut adalah aturan permainan yang dikembangan dalam permainan Domano ini dapat dilihat dalam Tabel 5.

Tabel 5. Aturan Permainan Kartu DOMANO

\begin{tabular}{ll}
\hline No & \multicolumn{1}{c}{ Deskripsi } \\
\hline $\mathbf{1}$ & Permainan dilakukan di dalam kelompok yang terdiri dari 3-4 orang pemain. \\
\hline $\mathbf{2}$ & Kocok kartu dan bagikan 16 kartu sampai habis. \\
\hline $\mathbf{3}$ & Peserta diberikan waktu maksimal 15 menit untuk mengerjakan soal yang didapat terlebih dahulu. \\
\hline $\mathbf{4}$ & $\begin{array}{l}\text { Pemain pertama ditentukan dengan undian. Jika jumlah kartu yang didapat tidak sama banyak, pemain } \\
\text { dengan jumlah kartu terbanyak mendapat giliran mengeluarkan kartu terlebih dahulu. }\end{array}$ \\
\hline $\mathbf{5}$ & $\begin{array}{l}\text { Pemain pertama diberi kebebasan untuk memasangkan : a)soal pada pasangan jawaban, atau b) jawaban } \\
\text { pada pasangan soal }\end{array}$ \\
\hline $\mathbf{6}$ & Ketika kartu dikeluarkan, peserta lain wajib mencatat dan menghitung jawaban dari soal tersebut \\
\hline $\mathbf{7}$ & $\begin{array}{l}\text { Pemain memasangkan kartu sedemikian rupa, sehingga terdapat pasangan soal dan jawaban yang tepat. } \\
\text { Hal ini dilakukan secara terus menerus hingga seluruh kartu habis. }\end{array}$ \\
\hline $\mathbf{8}$ & $\begin{array}{l}\text { Jika seluruh pemain tidak dapat menjawab ataupun merasa kesulitan, pemain yang mendapat giliran } \\
\text { berhak untuk melihat answer } \text { key dan mempelajari jawabannya. Setelah dipelajari, peserta diwajibkan } \\
\text { untuk menerangkan pemain lain yang belum mengerti }\end{array}$ \\
\hline
\end{tabular}

\section{d. Kunci Jawaban Kartu Domano}

Kunci jawaban kartu Domano ini terdiri dari tiga jilid jawaban dari masing-masing kartu. Tujuan utama dari pemberian kunci jawaban kartu Domano ini adalah untuk memfasilitasi mahasiswa jika dalam kelompok permainan tidak ada seorang pun yang dapat menjawab kartu yang didapatinya. Kunci jawaban ini akan membantu mahasiswa tersebut untuk menjawab pertanyaanya. Kunci jawaban ini bersifat alternatif karena tidak dapat digunakan langsung ataupun secara sembarang.

\section{e. Kotak Pengemasan Kartu Domano}

Kotak pengemasan ini dibentuk dengan tujuan agar seluruh perangkat yang dikembangkan (tiga set kartu Domano, aturan permainan, papan permainan, dan kunci jawaban kartu) dapat masuk kedalam kotak dan memudahkan dalam aksesbilitas dan mobilitas dari penggunaan kartu tersebut seperti Gambar 6.

\section{Kendala Pembuatan Kartu Domano}

Selama proses penyusunan dan pengembangan kartu Domano ini terdapat beberapa kendala diantaranya: (1) sulit untuk memilih dan menentukan soal yang cocok digunakan di kartu; (2) dalam proses percetakan kartu tidak dapat dicetak bolak-balik secara presisi karena keterbatasan alat; (3) proses penyusunan pasangan dan jawaban kartu cukup sulit karena harus mempertimbangkan banyak komponen. 


\section{Kelemahan dan Kekuatan Kartu Domano}

Kelemahan utama dari kartu ini adalah: (1) Peneliti sulit untuk mendeteksi kesalahan pemasangan kartu ketika kartu dimainkan dalam kelompok karena tidak ada kode yang memudahkan peneliti untuk mengkoreksi; (2) Soal yang dapat dituliskan di kartu Domano terbatas hanya maksimal 50 kata karena kecilnya ruang pada kartu; (3) Tidak boleh terdapat jawaban yang sama dan (4) Kelompok belajar harus heterogen.

Kekuatan utama dari kartu Domano ini adalah: (1) memiliki desain dan bahan yang sangat baik; (2) memiliki beragam variansi soal; (3) aturan permainan yang dapat melatih seluruh kemampuan belajar dan mengajar mahasiswa; (4) penggunaannya yang praktis karena seluruh perangkat terdapat dalam satu kotak.

\section{Tahap Uji Coba Media Kartu Domano \\ a. Validitas Ahli}

Media Kartu Domano ini akan divalidasi oleh validator yaitu ahli media dan ahli materi. Instrumen validasi terdiri dari 8 aspek materi dan 7 aspek tampilan. Validasi dilakukan untuk memperoleh kritik dan saran dari para ahli untuk melihat kesiapan dan kelayakan media ini sebelum digunakan di kelas. Kritik dan saran dari validator akan menjadi acuan dan pertimbangan dari pengembangan Kartu Domano ini.

\section{b. Revisi Produk}

Produk media kartu yang dikembangakan dapat dilihat pada Gambar 6. Revisi dari produk yang pertama kali dikembangkan ini disesuaikan dengan kritik dan saran yang diberikan oleh validator. Saran, kritik, dan tindak lanjut diuraikan pada Tabel 6.

Tabel 6. Saran, Kritik, dan Tindak Lanjut Kartu Edisi Kesatu

\begin{tabular}{|c|c|}
\hline Saran dan Kritik & Tindak Lanjut \\
\hline \multicolumn{2}{|l|}{ Tampilan } \\
\hline$>$ Desain yang kurang menarik & $\begin{array}{l}\checkmark \text { Membuat desain baru yang lebih berwarna dan menarik } \\
\text { khususnya untuk bagian latar belakang kartu }\end{array}$ \\
\hline$>$ Tinta yang mudah luntur & $\begin{array}{l}\checkmark \text { Memilih percetakan yang memiliki printer yang mempunyai tinta } \\
\text { yang jauh lebih baik }\end{array}$ \\
\hline$>$ Bahan yang kurang kuat & $\checkmark$ Mengganti bahan dasar kartu menjadi kertas A3 Ekstensi 260gsm \\
\hline \multicolumn{2}{|l|}{ Materi } \\
\hline$>$ Konten isi yang terlalu luas & $\checkmark$ Isi hanya difokuskan ke dalam 6 indikator yang akan diujikan \\
\hline $\begin{array}{l}\text { Pemilihan soal yang kurang sesuai } \\
\text { dengan Standar Kompetensi dan } \\
\text { Kompetensi Dasar }\end{array}$ & $\checkmark$ Mengkonsultasikan soal dengan dosen pengampu mata kuliah \\
\hline $\begin{array}{l}\text { Konsep sulit, sedang, dan mudah } \\
\text { yang tidak sesuai }\end{array}$ & $\begin{array}{l}\checkmark \text { Menghapus konsep } 3 \text { tingkatan kartu (sulit, sedang, mudah) dan } \\
\text { menggantikan dengan } 3 \text { jenis kartu (putih, abu-abu, dan hitam) }\end{array}$ \\
\hline
\end{tabular}

Setelah diadakan tindak lanjut untuk pengembangan produk Kartu Domano pertama, kemudian dibuatlah kartu dengan nama Kartu Dota (Domino of Trigonometry Application) . Kemudian kartu edisi kedua ini divalidasi kembali kepada kedua validator dan diberi saran, dan kritik yang diuraikan pada Tabel 7.

Tabel 7. Saran, Kritik, dan Tindak Lanjut Kartu Edisi Kedua

\begin{tabular}{ll}
\hline \multicolumn{3}{c}{ Saran dan Kritik } & Tindak Lanjut \\
\hline Tampilan & \\
\hline $\begin{array}{l}\text { Warna dari ketiga kartu kurang } \\
\text { kontras }\end{array}$ & $\begin{array}{c}\checkmark \text { Perubahan dan pemilihan warna kartu menjadi (merah, kuning, dan } \\
\text { hitam) }\end{array}$ \\
$\begin{array}{l}\text { Jumlah kartu yang tidak seimbang } \\
(16,24 \text {, dan 32) }\end{array}$ & Merubah jumlah dari masing-masing kartu menjadi 16 buah \\
Nama kartu DOTA yang kurang & $\checkmark$ Merubah nama kartu menjadi kartu Domano (Domino Matematika \\
sesuai dengan SK dan KD & Trigonometri) \\
$\begin{array}{l}\text { Pengemasan Kartu yang kurang } \\
\text { baik }\end{array}$ & $\begin{array}{l}\checkmark \text { Membuat dan menyiapkan kotak untuk pengemasan kartu serta } \\
\text { kotak untuk pengemasan keseluruhan perangkat permainan kartu }\end{array}$ \\
$\begin{array}{l}\text { Desain latar belakang kartu kurang } \\
\text { baik }\end{array}$ & $\checkmark$ Memano \\
\hline
\end{tabular}




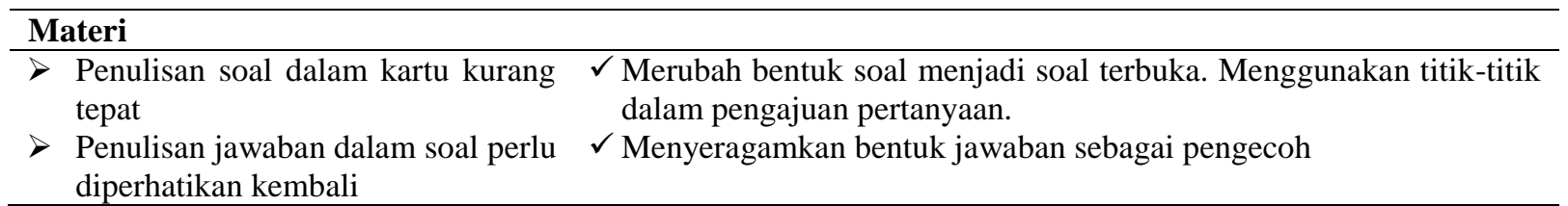

Setelah melalui dua tahap validasi kemudian disusun dan dibuat kartu edisi ketiga seperti Gambar 7.

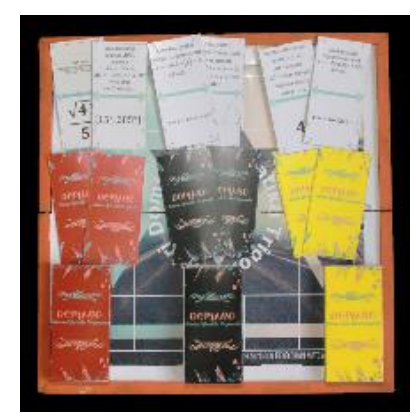

Gambar 7. Perangkat Kartu Domano

Perbaikan yang telah dilakukan pada kartu edisi ketiga ini dinilai cukup dan disimpulkan kartu Domano ini sudah layak dan dapat digunakan dalam penelitian.

\section{Implementation (Implementasi)}

Penelitian dilakukan di kelas asistensi mata kuliah Trigonometri. Penggunaan media Kartu Domano yang dikembangkan ini akan digunakan sebagai media lantihan soal mandiri pada materi Trigonometri. Respons mahasiswa diperoleh berdasarkan hasil pretest, posttest, dan lembar pendapat mahasiswa. Instrumen penelitian dari angket kepraktisan akan diisi oleh dosen pengampu mata kuliah Trigonometri, dan pengajar kelas asistensi Trigonometri. Pretest merupakan tes untuk mengetahui kemampuan awal mahasiswa sebelum menggunakan media kartu Domano yang terdiri dari 20 soal pilihan ganda. Setelah dilakukan pretest kemudian diberikan media Kartu Domano untuk digunakan oleh mahasiswa selama 1 minggu dengan total dua kali penggunaan keseluruhan tiga kartu.

Pada kali pertama hanya digunakan satu kartu karena mahasiswa masih membiasakan diri dalam menggunakan kartu Domano ini. Dalam penggunaan kali kedua, seluruh mahasiswa memainkan dua jenis kartu lainnya yang belum dimainkan pada kali pertama, sehingga seluruh mahasiswa total memainkan tiga jenis kartu Domano. Kemudian setelah dua kali penggunaan media ini dilakukan posttest yang terdiri dari 20 soal pilihan ganda yang identik dengan soal pretest. Hasil dari posttest akan dibandingkan dengan pretest yang telah diperoleh sebelumnya untuk mengetahui sejauh apa dampak yang diperoleh dari penggunaan media kartu Domano ini.

\section{Evaluation (Evaluasi)}

Tahap evaluasi bertujuan untuk mengetahui kelebihan dan kekurangan dari media kartu Domano, dan hasil belajar Trigonometrinya. Hasil dari tahap evaluasi dijadikan dasar untuk perbaikan media kedepannya. Hasil evaluasi dijelaskan sebagai berikut.

\section{Analisis Validitas Media}

Tahap analisis data validasi berdasarkan pada penilaian validator meliputi aspek media dan aspek tampilan. Kedua aspek dijelaskan sebagai berikut :

\section{a. Aspek Tampilan}

Aspek tampilan terdiri dari 7 indikator, berdasarkan penilaian dari 2 validator diperoleh persentase rata-rata sebesar $98.71 \%$ dan masuk dalam kategori sangat baik.

\section{b. Aspek Materi}

Aspek materi terdiri dari 8 indikator, berdasarkan penilaian dari 2 validator diperoleh persentase rata-rata sebesar $92.5 \%$ dan masuk dalam kategori sangat baik.

\section{Analisis Data keefektifan}

Keefektifan media kartu Domano diperoleh berdasarkan hasil dari pretest, posttest, dan lembar pendapat mahasiswa. Nilai pretest dan posttest dari subjek dijelaskan secara deskriptif pada Tabel 7. 
Tabel 7. Data Nilai Pretest dan Posttest Mahasiswa Pendidikan Matematika

\begin{tabular}{llll}
\hline Pretest & \multicolumn{3}{l}{ Posttest } \\
\hline Rata-Rata & Std. Dev & Rata-Rata & Standar Deviasi \\
\hline 57.26 & 20.21 & 73.72 & 18.26
\end{tabular}

Data hasil belajar pretest dan posttest mahasiswa yang telah terkumpul, kemudian dianalisis signifikansi peningkatannya dengan menggunakan uji Paired T- test menggunakan program SPSS 17. Berdasarkan data perhitungan didapat nilai Sig. (2-tailed) sebesar 0.000 sehingga dapat disimpulkan terdapat perbedaan rerata yang signifikan atas penggunaan media Kartu Domano. Hasil tersebut menunjukan bahwa kartu Domano efektif bagi mahasiswa Pendidikan Matematika UKSW angkatan 2016 dalam mata kuliah Trigonometri karena terdapat perbedaan rerata yang signifikan sebesar 16.5 poin atau dapat dikatakan meningkat.

\section{Analisis Data Kepraktisan.}

Kepraktisan penggunaan media kartu Domano diperoleh dari angket kepraktisan yang diisi oleh dosen pengampu mata kuliah Trigonometri serta pengajar kelas asistensi Trigonometri. Rata-rata nilai kepraktisan yang diperoleh dari penggunaan kartu Domano ini sebesar $89 \%$ yang masuk dalam kategori sangat baik.

Berdasarkan hasil analisis pendapat mahasiswa untuk indikator tampilan pada kartu Domano diperoleh hasil tingkat kepuasan sebesar $85.93 \%$ (sangat setuju), untuk indikator ketertarikan minat mahasiswa untuk berlatih soal Trigonometri dengan menggunakan kartu Domano didapat nilai kepuasan sebesar $83.12 \%$ (sangat setuju), untuk indikator kemudahan dalam memahami materi Trigonometri melalui penggunaan kartu Domano didapat nilai kepuasan sebesar 82.18\% (sangat setuju), untuk indikator kemudahan mahasiswa untuk berlatih soal Trigonometri secara mandiri sebesar $85.31 \%$ (sangat setuju), dan untuk indikator pengembangan media Domano untuk materi Trigonometri selanjutnya didapat nilai $84.68 \%$ (sangat setuju).

Mahasiswa menyukai tampilan dari media karena berwarna dan mempunyai tulisan yang mudah dibaca. Menurut mahasiswa ketertarikan mereka atas kartu Domano karena mereka merasa tertantang untuk menjawab, menyelesaikan permainan, dan dapat belajar sekaligus bermain. Mahasiswa setuju agar kartu Domano disusun untuk materi selanjutnya karena dapat memudahkan dalam mengerjakan latihan soal secara berkelompok sehinggaberlatih soal dapat berjalan dengan baik dengan cara yang tidak membosankan.

\section{PEMBAHASAN}

\section{Validitas Kartu Domano}

Kartu Domano ini digunakan dikelas sebagai media latihan soal yang akan membantu mahasiswa untuk berlatih soal mandiri dengan cara yang menyenangkan dan tidak membosankan. Perangkat kartu Domano yang dikembangkan meliputi 3 set kartu Domano (merah, kuning, hitam), 8 buah papan permainan kartu Domano, sebuah aturan permainan, 3 set kunci jawaban kartu, serta kotak sebagai tempat pengemasan kartu. Setiap set kartu berisi 16 pasangan soal dan jawaban yang harus dirangkai oleh mahasiswa pada papan permainan. Tujuan dari permainan ini bukan hanya mahasiswa dapat mengerjakan dan berlatih soal mandiri namun mahasiswa mampu saling mengajari mahasiswa yang lain.

Media Kartu Domano ini telah melalui 3 kali tahap revisi oleh 2 validator yaitu validator ahli dan validator media. Revisi pun telah dilakukan berdasarkan saran dan masukan dari tiap-tiap validator. Berdasarkan hasil validasi akhir pada aspek tampilan memperoleh persentase sebesar 98.71\% yang termasuk dalam kategori sangat baik. Kategori sangat baik ini meliputi, bentuk dan ukuran media yang seimbang, ukuran dan warna huruf yang baik, desain latar belakang kartu yang baik, tidak membosankan, dan pengemasan media yang sangat baik di dalam satu kotak untuk memudahkan dalam penggunaannya. Aspek materi memperoleh persentase sebesar $92.5 \%$ dengan kategori sangat baik. Kategori sangat baik ini meliputi, pemilihan soal yang baik sesuai dengan kemampuan belajar mahasiswa, beberapa soal juga dapat menantang mahasiswa untuk berpikir lebih, penyusunan dan proporsi soal telah sesuai dengan kurikulum yang diajarkan dalam mata kuliah Trigonometri. 


\section{Keefektifan Kartu DOMANO}

Hasil uji kemampuan mahasiswa berdasarkan pretest dan posttest dianalisis dan dihitung pengaruhnya menggunakan Paired Samples T- tests. Berdasarkan perhitungan menggunakan software SPSS 17 hasil test tersebut mengalami peningkatan 16.47 poin. Gambaran hasil dari pretest dan posttest disajikan dalam Diagram 2.

Berdasarkan perhitungan melalui SPSS didapat kesimpulan bahwa terdapat peningkatan yang signifikan setelah penggunaan media Kartu Domano pada mahasiswa subjek. Disimpulkan bahwa media Kartu Domano pada materi Trigonometri ini efektif digunakan sebagai media latihan soal mandiri bagi mahasiswa. Hasil penelitian ini juga mendapatkan hasil yang tidak berbeda dengan penelitian dilakukan oleh Larasati \& Poedjiastuti (2016) tentang mengembangkan kartu domino pada materi unsur bagi siswa SMALB tunarungu memberikan hasil belajar dengan peningkatan skor gain pada kategori sedang. Kemudian hasil ini serupa dengan penelitian Aprinawati (2017) yang mendapatkan bahwa penggunaan media kartu domino bilangan dapat meningkatkan hasil belajar matematika siswa kelas V SD.

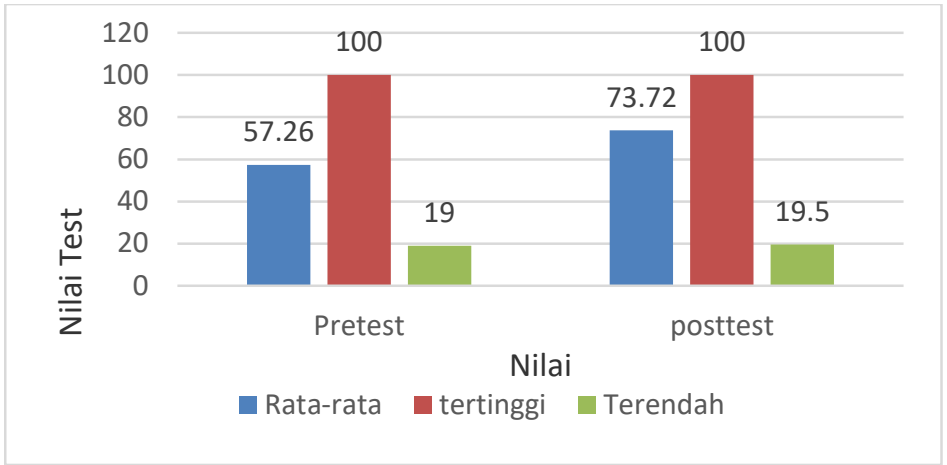

Diagram 2. Data Nilai Tes Mahasiswa

\section{Kepraktisan Penggunaan Media Kartu Domano}

Berdasarkan hasil analisis angket kepraktisan kartu Domano dari 3 responden diperoleh persentase sebesar $89 \%$ dan termasuk dalam kategori sangat baik. Kategori sangat baik ini meliputi, penggunaanya yang relatif mudah, pengemasan yang sangat baik sehingga hanya perlu membawa satu kotak yang berisi seluruh perangkat kartu Domano tersebut, bahan Kartu Domano yang awet dan dapat digunakan berulang kali, dan penggunaanya yang tidak terbatas waktu dan tempat sehingga dapat memfasilitasi mahasiswa untuk berlatih soal mandiri. Secara keseluruhan dapat disimpulkan bahwa Media Kartu Domano pada materi Trigonometri praktis digunakan dalam pembelajaran sebagai media latihan soal mandiri.

Analisis lembar pendapat mahasiswa secara keseluruhan bahwa media kartu Domano ini menarik mahasiswa untuk berlatih soal menggunakan media ini. Kartu Domano mempunyai tampilan yang sangat menarik, berwarna dan mempunyai ukuran huruf dan warna yang baik sehingga memudahkan mahasiswa dalam penggunaan dan pengerjaan soalnya. Mahasiswa menyukai kartu Domano ini karena mereka dapat bermain sekaligus belajar sehingga berlatih soal tidak membosankan. Pengerjaan soal yang bersama-sama juga memudahkan mahasiswa untuk menjawab soal dan bertukar pikiran mengenai soal yang didapatnya.

Kartu Domano ini mengadopsi permainan kartu domino konvensional sehingga dalam penggunaannya mudah dipahami oleh mahasiswa. Namun ada beberapa mahasiswa yang mengeluhkan beberapa soal yang didapat tergolong sukar sehingga mereka kesulitan untuk mengerjakannya. Pemberian kunci jawaban juga sangat menolong mahasiswa tatkala mereka kesulitan dalam mengerjakan soal.

Keseluruhan mahasiswa juga sangat setuju apabila media Kartu Domano ini dikembangkan untuk materi selanjutnya dalam mata kuliah Trigonometri ini menandakan motivasi dan minat belajar mahasiswa yang sangat baik atas penggunaan kartu Domano ini.

\section{SIMPULAN DAN SARAN}

Berdasarkan hasil penelitian dan pembahasan dapat disimpulkan bahwa pengembangan kartu Domano dengan model pengembangan ADDIE ini telah menghasilkan media pembelajaran yang 
valid, efektif, dan praktis untuk digunakan pada mata kuliah Trigonometri. Kartu Domano layak digunakan sebagai media latihan soal mandiri bagi mahasiswa. Media Kartu Domano ini dinilai baik untuk dikembangkan pada materi-materi trigonometri maupun materi matematika yang lainnya.

Saran bagi peneliti selanjutnya adalah pemanfaatan domino matematika ini dapat dicobakan untuk materi yang lain. Demikian juga domino matematika ini kemungkinan besar dapat juga dikembangkan dalam versi elektronik mungkin dalam bentuk game online.

\section{DAFTAR PUSTAKA}

Aprinawati, Iis. 2017. Penggunaan Media Kartu Domino Bilangan Dapat Meningkatkan Hasil Belajar Matematika Siswa Kelas V SD. Jurnal Pelangi stkip-pgri-sumbar 9(2), 123.

Arsyad, A. 2011. Media Pembelajaran. Jakarta: Rajawali Press.

Harjanto. 1997. Perencanaan Pengajaran. Jakarta: PT Rineka Cipta.

Indriana, D. 2011. Ragam Alat Bantu Media Pengajaran. Jogjakarta: Diva Press.

Kriswandani \& Wahyudi. 2013. Pengembangan Pembelajaran Matematika SD. Salatiga: Widya Sari Press.

Larasati, L. D., \& Poedjiastuti, S. (2016). Pengembangan Permainan Kartu Domino Kimia Sebagai Media Pembelajaran Pada Materi Unsur Bagi Siswa SMALB Tunarungu. UNESA Journal of Chemical Education 5(1), 115-119.

Nengsih, R. F., \& Rochmawati. (2014). Pengembangan Kartu Domino Sebagai Media Pembelajaran Akuntansi Pada Materi Ayat Jurnal Penyesuaian. Jurnal Pendidikan Akuntansi (JPAK) 2(2),67.

Petrus. 2013. Penerapan Alat Peraga IPA Terhadap Peningkatan Hasil Belajar Konsep Rangkaian Listrik dan Kemagnetan Pada Siswa Kelas VI SD Kristen Belakang Soyta A1 Ambon. Jurnal Dinamika Pendidikan 6(2), 2013, 82-92.

Pribadi, B. A. 2011. Model Desain Sistem Pembelajaran. Jakarta : Dian Rakyat.

Sadiman, A. S dkk. (2007). Media Pendidikan: pengertian, pengembangan, dan pemanfaatannya. Jakarta: PT. RajaGrafindo Persada.

Setyawati, R. D., \& Handayanto, A. (2011). Peningkatan Kualitas Pembelajaran Melalui Model Pembelajaran Problem Posing Tipe Presolution Posing Secara berkelompok Berbasis Karakter Bangsa. Jurnal AKSIOMA 2(2), 1-10.

Sugiyono. 2010. Metode penelitian pendidikan. Bandung: Alfabeta

Sukmadinata, N. S. 2009. Metode Penelitian Pendidikan. Bandung: PT Remaja Rosdakarya.

Sundayana, R. 2013. Media Pembelajaran Matematika. Bandung: Alfabeta.

Syafik, A. 2012. Permainan Matematika Sebagai Metode Alternatif Dalam Pembelajaran Matematika Pada Siswa Kelas I Sekolah Dasar. Jurnal LIMIT-Pendidikan Matematika, 02 (2), 21-36. 